\title{
Pembibitan (Kultur Jaringan hingga Pembesaran) Anggrek Phalaenopsis di Hasanudin Orchids, Jawa Timur
}

\author{
Nursery (Tissue Culture up to Enlargement) of Phalaenopsis Orchids in Hasanudin Orchids, \\ East Java
}

\author{
Zahra Fadhlia Yasmin, Syarifah Iis Aisyah* dan Dewi Sukma \\ Departemen Agronomi dan Hortikultura, Fakultas Pertanian, Institut Pertanian Bogor \\ Jalan Meranti, Kampus IPB Dramaga, Bogor 16680, Indonesia \\ Telp.\& Faks. 0251-8629353 e-mail: agronipb@indo.net.id \\ *Penulis untuk korespondensi : syarifahiis@yahoo.com
}

Disetujui 20 Agustus 2018 / Published online 3 September 2018

\begin{abstract}
The research was conducted at the Hasanudin Orchids garden, Batu, East Java in the aspect of Phalaenopsis orchid cultivation. The objective of this internship is to study the Phalaenopsis orchid breeding process from tissue culture to enlargement to produce high-value crops at Hasanudin Orchid. The result of observation showed that PDA culture media has $7 \%$ contamination while VW media has $22 \%$. The process of germination or subculture, especially on sub-culture 2 excessively found contamination. This happens because of several factors, including planlet that has wound on the media replacement process. The percentage of success of acclimatization is $100 \%$. Prevention of loss due to contamination needs to be considered seriously. Plants ranging from young seedlings, teen lants, and adult plants in two green houses showed no significant difference. Some development needs to be done in order to produce crops with high selling value.
\end{abstract}

Key words: acclimatization, culture media, repotting

\begin{abstract}
ABSTRAK
Kegiatan penelitian di kebun Hasanudin Orchids bertujuan meningkatkan pengetahuan dan keterampilan mahasiswa dalam aspek budidaya anggrek Phalaenopsis. Tujuan secara khusus pada penelitian ini adalah mempelajari proses pembibitan anggrek Phalaenopsis dari kultur jaringan hingga pembesaranuntuk menghasilkan tanaman yang bernilai jual tinggi di Hasanudin Orchid. Hasil pengamatan menunjukkan pada pembuatan media kultur PDA terjadi kontaminasi sebesar 7\% dan media VW sebesar $22 \%$. Proses penyemaian atau sub kultur, terutama pada sub kultur 1 banyak ditemukan kontaminasi. Hal ini terjadi karena beberapa faktor, diantaranya planlet yang luka pada saat pindah media. Persentase keberhasilan pada saat aklimatisasi adalah 100\%. Pencegahan kehilangan akibat kontaminasi perlu diperhatikan secara intensif. Pembibitan mulai dari bibit muda, tanaman remaja, dan tanaman dewasa di dua green house tidak menunjukkan perbedaan signifikan. Perlu dilakukan beberapa pengembangan agar menghasilkan tanaman yang bernilai jual tinggi.
\end{abstract}

Kata kunci: aklimatisasi, media kultur, pindah tanam 


\section{PENDAHULUAN}

Anggrek merupakan tanaman hias yang termasuk ke dalam famili Orchidaceae yang menarik perhatian konsumen. Selain mempunyai nilai estetika yang tinggi anggrek juga mempunyai bentuk, ukuran, dan warna bunganya yang sangat bervariasi. Daya tahan atau kesegaran bunga anggrek yang relatif lama menjadi faktor tingginya nilai ekonomi anggrek, sehingga memberikan prospek pasar yang cukup cerah dan meningkatkan minat para pemulia tanaman untuk menghasilkan anggrek hibrida baru. Produksi tanaman anggrek di Indonesia pada tahun 2015 adalah 21.514.789 tanaman. Angka ini menunjukkan bahwa anggrek berada pada posisi ketiga setelah krisan dan mawar (Badan Pusat Statistik, 2015). Anggrek Phalaenopsis merupakan jenis anggrek terbanyak $(80 \%)$ dari semua anggrek yang dijual di pasar dunia (Wu dan Chay, 2012).

Teknik kultur in vitro dilakukan untuk memenuhi kebutuhan anggrek Phalaenopsis dalam jumlah yang besar dan kualitas bunga yang seragam, (Young et a.l, 2001). Sebelum ditanam sebagai bibit dalam pot, bibit anggrek hasil perbanyakan in vitro memerlukan suatu tahap penyesuaian terhadap cekaman lingkungan yang baru, yang disebut tahap aklimatisasi. Tahap akhir dalam kegiatan budidaya tanaman secara kultur jaringan adalah aklimatisasi. Aklimatisasi dapat dilakukan jika planlet sudah memiliki organ lengkap yang umumnya berumur delapan hingga dua belas bulan. Aklimatisasi merupakan proses penyesuaian terhadap iklim pada lingkungan baru yang merupakan masalah penting dalam budidaya tanaman menggunakan bibit dari teknik kultur jaringan (Handini 2012).

Protocorm anggrek yang sudah menjadi planlet pada saat aklimatisasi harus segera dipindahkan ke dalam pot. Hal ini ditujukan agar tanaman planlet memiliki ruang tumbuh yang lebih baik. Pembibitan biasanya dilakukan di dalam green house untuk memberikan kondisi lingkungan anggrek Phalaenopsis yang optimal, yaitu memiliki suhu berkisar antara $15-35{ }^{\circ} \mathrm{C}$, kelembaban udara 70-80\%, intensitas sinar matahari 12.000-20.000 lux, semi teduh atau semi naungan berkisar antara $15-30 \%$.

Pengembangan usaha budidaya anggrek meliputi berbagai aspek pembibitan dan pemeliharaan. Aspek penting yang perlu diperhatikan adalah penanaman, media tanam, penyiraman, pengelolaan pemupukan, dan pengendalian hama dan penyakit, terutama pada fase pembibitan, baik saat tanaman masih ditanam dalam kompot maupun dalam individual
pot.Kegiatan penelitian ini bertujuan untuk meningkatkan pengetahuan dan keterampilan mahasiswa dalam aspek budidaya anggrek Phalaenopsis. Tujuan secara khusus pada penelitian ini adalah untuk mempelajari proses pembibitan anggrek Phalaenopsis dari kultur jaringan hingga pembesaran untuk menghasilkan tanaman yang bernilai jual tinggi di Hasanudin Orchids.

\section{METODE PENELITIAN}

Kegiatan penelitian dilaksanakan di laboratorium dan nursery anggrek Hasanudin Orchids, Batu, Jawa Timur selama 4 bulan dengan menggunakan dua metode langsung dan tidak langsung. Metode langsung dilakukan dengan mengikuti seluruh kegiatan teknis di laboratorium dan kebun serta pengamatan pada beberapa variabel. Metode tidak langsung dilakukan dengan mengumpulkan data sekunder dari perusahaan. Pada kegiatan ini, penulis bekerja secara langsung di lapangan sebagai karyawan harian lepas (KHL). Kegiatan yang berlangsung setiap hari ditulis dalam jurnal harian. Kegiatan yang dilaksanakan oleh penulis yaitu membuat media kultur VW (modifikasi), media PDA, penyemaian benih, sub kultur, aklimatisasi, penyiapan media tanam, repotting, pemupukan, dan pengendalian hama dan penyakit dan pengemasan (packing). Pelaksanaan kegiatan tersebut disesuaikan dengan kegiatan kebun pada saat kegiatan penelitian berlangsung.

Pengamatan dilakukan di $2 \mathrm{GH}$ dengan ketinggian yang berbeda dan desain $\mathrm{GH}$ yang berbeda. Ketinnggian GH 1 adalah 680 meter diatas permukaan laut dengan plastik uv berada di bawah paranet, sedangkan ketinggian $\mathrm{GH} 2$ adalah 770 meter diatas permukaan laut dengan plastic uv berada di atas paranet. Pengamatan dilakukan untuk memperoleh data primer adalah (1) Persentase kontaminasi media PDA dan media VW. Pengamatan dilakukan selama empat bulan. (2) Persentase kontaminasi pada planlet. Pengamatan dilakukan selama empat bulan. (3) Persentase keberhasilan aklimatisasi. Pengamatan dilakukan selama empat bulan. (4) Rata-rata tinggi tanaman, jumlah daun, panjang daun, dan lebar daun pada fase bibit muda, tanaman remaja, dan tanaman dewasa. Pengamatan dilakukan selama 7 MSP. (5) persentase serangan hama dan penyakit. Data juga diuji menggunakan rata-rata dan standar deviasi Ms. Excel 


\section{HASIL DAN PEMBAHASAN}

\section{Pembuatan Media Kultur}

Tingkat keberhasilan perkecambahan biji anggrek secara in vitro umumnya sangat tinggi jika syaratnya terpenuhi yaitu kondisi yang aseptik pada biji dan media kultur, kecukupan kandungan gula sebagai sumber energi dan kecukupan nutrisi dan senyawa organik yang diperlukan untuk perkecambahan dan pertumbuhan protocorm menjadi seedling (Yusnita, 2012). Berdasarkan persyaratan tersebut,formulasi media tanam sangat mempengaruhi pertumbuhan anggrek secara in vitro, sampai saat ini telah banyak dilakukan penelitian mengenai media tanam yang cocok untuk pertumbuhan dan perkembangan anggrek secara in vitro.

Menurut Yusnita (2012), ada beberapa jenis formulasi media dasar yang umum digunakan untuk pengecambahan biji dan pembesaran seedling anggrek secara in vitro. Media kultur yang dibuat untuk perbanyakan tanaman di Hasanudin Orchids ada dua, yaitu media PDA (Potato Dextrose Agar) dan media VW (Vacint and Went) modifikasi. Media PDA dibuat untuk media kultur biji pada fase pertama. Hal ini dilakukan agar biji dapat berkecambah dengan baik karena media PDA mengandung ekstrak kentang dan karbohidrat yang cukup untuk menggantikan cadangan makanan yang tidak terdapat pada biji anggrek.

Media tumbuh yang biasa digunakan untuk pembesaran anggrek adalah media VW (Vacint and Went), (Bey et al., 2006). Media VW digunakan oleh HO pada saat penanaman planlet yang telah terbentuk daun dan akar, tetapi belum terbentuk sempurna. Air kelapa $150 \mathrm{ml} \mathrm{L}^{-1}$ pada

Tabel 1. Persentase kontaminasi pada media media VW mampu mendorong pembentukan plb (protocorm like bodies) sebagai calon tanaman. Protocorm adalah bentukan bulat yang siap membentuk pucuk dan akar sebagai awal perkecambahan anggrek. Morel (1974) menyatakan, didalam air kelapa terkandung hormone sitokinin $5,8 \mathrm{mg} \mathrm{L}^{-1}$, auksin $0,07 \mathrm{mg}$ $\mathrm{L}^{-1}$ dan giberalin yang dapat menstimulasi perkecambahan dan pertumbuhan tanaman, berfungsi sebagai penstimulir dalam proliferasi jaringan, memperlancar metabolisme dan respirasi. Oleh karena itu air kelapa mempunyai kemampuan besar untuk mendorong pembelahan sel dan proses deferensiasi.

Media agar dibuat di dapur laboratorium sesuai dengan kebutuhan penanaman yang telah direncanakan. Komposisi media pun disesuaikan dan ditentukan sesuai kebutuhan penanaman. Bahan-bahan dicampur dan direbus hingga mendidih, kemudian dituangkan dalam botol bersih yang telah disiapkan. Botol kemudian ditutup menggunakan penutup karet yang telah disterilisasi. Botol-botol tersebut selanjutnya disterilisasi menggunakan autoclave.

Penulis melakukan pengamatan khusus pada pembuatan media kultur jaringan ini mengenai persentase kontaminasi media. Media sangat rawan terserang mikroorganisme kontaminan yang dapat menyebabkan tanaman tidak tumbuh bahkan mati. Hal ini dapat dikarenakan oleh tempat penyimpanan media yang terlalu lembab atau cara pembuatan media yang tidak sesuai, misalnya kurangnya pengadukan media pada saat akan dimasukan ke dalam botol. Oleh karena itu, cara pembuatan media harus diperhatikan dengan benar oleh karyawan. Berikut merupakan data persentase kontaminasi periode dapat dilihat pada Tabel 1 .

\begin{tabular}{lccc}
\hline Jenis Media Kultur & Total media & Jumlah terkontaminasi & Persentase (\%) \\
\hline Media PDA (Potato & 95 & 7 & 7 \\
Dextrose Agar) & & & 22 \\
MediaVW (Vacint dan & 1.536 & 338 & 17 \\
Went) Modifikasi & 2.055 & 345 & \\
Jumlah & & & \\
\hline
\end{tabular}

Berdasarkan pengamatan dapat dilihat bahwa media PDA hanya mengalami kontaminasi sebesar 7\%, sedangkan pada media VW (modifikasi) sebesar 22\%. Hal ini dapat disebabkan oleh beberapa factor, diantaranya pada proses akhir memasak yaitu kurang kuat dalam menutup botol dan tempat penyimpanan media. Penutupan tutup botol yang kurang kuat dapat mengakibatkan terjadinya pertukaran udara dari dalam dan luar botol, sehingga terjadinya kontaminasi. Tempat penyimpanan media VW (modifikasi) sangat lembab, sehingga media banyak terkontaminasi oleh cendawan. Untuk meminimalisir terjadinya kontaminasi, pekerja harus menutup botol dengan kuat dan media harus dipindahkan ke tempat yang tidak begitu lembab.

\section{Penyemaian dan Pembesaran Planlet}

Perbanyakan tanaman dilakukan secara in vitro menggunakan bahan tanam yang berasal dari 
seedling (biji). Menurut Bieniek et al. (2010), jumlah biji yang dihasilkan dalam satu kapsul anggrek sangat banyak namun hanya sedikit yang dapat berkecambah dan tumbuh di alam. Hal ini terjadi karena ukuran biji anggrek yang sangat kecil dan ringan dengan panjang 0,25-1,2 $\mathrm{mm}$ dan berat 0,3-1,4 $\mu \mathrm{g}$. Biji anggrek tidak mempunyai endosperm sebagai cadangan makanan yang diperlukan pada awal perkecambahan (Yusnida et al., 2006). Biji anggrek dikenal dengan sebutan "Dust Seed" (Amilah dan Yuni, 2006), karena dalam tiap kapsul anggrek dapat menghasilkan jutaan biji (Dutta et al., 2011). Bahan tanam yang digunakan merupakan biji dari buah yang dihasilkan oleh perusahaan melalui penyilangan. Pertumbuhan planlet melalui beberapa fase yaitu awal penyemaian, fase sub kultur 1, sub kultur 2, dan sub kultur 3 (sub kultur terakhir).

Penanaman dilakukan di dalam entkas, dimana entkas harus disterilisasi terlebih dahulu minimal 8 jam sebelum pemakaian. Alat dan bahan tanam disterilisasikan menggunakan pemutih pakaian. Bagian dalam entkas disemprot dan dibersihkan dengan alkohol $80 \%$, kemudian entkas ditutup selama 8 jam. Setelah 8 jam entkas dapat digunakan. Sebelum digunakan, alat disterilisasi lagi dengan membakarnya di atas bunsen selama 25-30 detik.

Buah disterilisasi terlebih dahulu dengan mencelupkannya ke dalam alkohol $80 \%$. Pembelahan buah dilakukan menggunakan pisau yang steril. Buah dibelah dan ditabur ke dalam botol yang berisi larutan media cair khusus. Ujung botol dibakar dengan pembakar dan ditutup rapat menggunakan tutup karet dan plastik yang telah diberi kode buah, tanggal penanaman, dan inisial perusahaan kemudian disimpan di ruang tumbuh.

Proses pertumbuhan biji hingga menjadi planlet yang siap akan diaklimatisasi melalui beberapa fase, yaitu :
1. Penyemaian, yaitu penanaman pertaman biji dari buah yang telah dibelah di media kultur PDA hingga tumbuh menjadi protocorm dan berkembang menjadi planlet kecil yang telah terbentuk daun dan akarnya sekitar 1-2 mm. Planlet saat itu siap dipindahkan ke media baru atau media VW (modifikasi).

2. Sub kultur 1, yaitu sub kultur planlet dari fase sebelumnya yang telah terbentuk daun dan akarnya walaupun belum sempurna. Tujuannya untuk memberikan ruang tumbuh yang lebih luas, sehingga jumlah planletnya lebih sedikit dibandingkan pada penyemaian . Fase ini berlangsung selama 3-4 bulan.

3. Sub kultur 2, yaitu sub kultur planlet dari sub sebelumnya yang ditekankan pada pengembangan daun dan akar tanaman. Planlet dari botol lama di-sub kultur ke dalam botol berisi media baru sebanyak 20 planlet per botolnya. Planlet dibiarkan tumbuh selama 3-4 bulan hingga berukuran 3-5 $\mathrm{mm}$.

4. Sub kultur 3, yaitu sub kultur planlet dari fase sebelumnya yang lebih ditekankan pada pengembangan akar tanaman. Planlet disimpan selama 3-4 bulan, selanjutnya planlet siap di aklimatisasi.

Biji yang disemai selama kegiatan penelitian berlangsung berasal dari 2 buah anggrek Phalaenopsis. Kegiatan penyemaian dan sub kultur harus memperhatikan kebersihan tempat, alat, bahan, dan pelaksana penanaman. Hal ini bertujuan untuk meminimalisir kemungkinan terjadinya kontaminasi planlet yang ditanam. Berdasarkan pengamatan yang dilakukan penulis mengenai persentase penanaman planlet dapat dilihat pada Tabel 2.

Tabel 2. Persentase kontaminasi pada planlet

\begin{tabular}{lccc}
\hline Fase & $\begin{array}{c}\text { Jumlah total } \\
\text { (botol) }\end{array}$ & $\begin{array}{c}\text { Jumlah kontaminasi } \\
\text { (botol) }\end{array}$ & Persentase (\%) \\
\hline Penyemaian & 2 & 0 & 0 \\
Sub kultur 1 & 18 & 5 & 28 \\
Sub kultur 2 & 10 & 2 & 20 \\
Sub kultur 3 & 5 & 0 & 0 \\
\hline
\end{tabular}

Menurut (Hendaryono dan Wijoyono, 1994) Sub kultur adalah pemindahan tanaman kultur in vitro ke dalam media baru, sehingga kebutuhan nutrisi untuk pertumbuhan kalus, protocorm, dan organ dapat terpenuhi. Berdasarkan pengamatan (Tabel 2) persentase kontaminasi banyak terjadi pada sub kultur 1 . Hal ini dapat terjadi karena beberapa faktor, diantaranya planlet yang luka saat pindah media.
Menurut Laukkanen et al. (1999) dalam Hutami (2008), ketika sel rusak, isi dari sitoplasma dan vakuola menjadi tercampur, kemudian senyawa fenol teroksidasi menghambat aktivitas enzim. Senyawa fenol yang berlebihan akan bersifat racun yang merusak jaringan planlet dan akhirnya menyebabkan kematian planlet (Corduk and Aki, 2011). Tingginya tingkat kontaminasi pada sub 
kultur harus diminimalisir dengan ketelitian para pekerja.

\section{Aklimatisasi Planlet (Outflask)}

Aklimatisasi bibit (outflask) merupakan kegiatan memindahkan bibit dari botol dan ditanam di dalam pot dengan media moss. Bibit tanaman berupa bibit dalam botol yang berasal dari perbanyakan generatif dengan seedling yang sebelumnya telah dikembangbiakan di laboratorium. Bibit dalam botol yang dapat ditanam dalam pot kompot adalah bibit yang telah memiliki minimal dua akar dan dua daun.

Kegiatan dalam aklimatisasi ini meliputi persiapan bibit dan penanaman bibit dalam pot. Pada persiapan bibit dilakukan beberapa kegiatan yaitu pencabutan atau pengeluaran bibit dari botol, pencucian bibit dan pengeringan bibit. Pencabutan atau pengeluaran bibit dari botol dilakukan dengan mengeluarkan satu persatu bibit dari botol dengan menggunakan kawat dengan ujung huruf U. Tanaman yang telah dikeluarkan dari botol kultur kemudian dicuci sebanyak dua kali dengan air dan dikeringkan agar tanaman tidak busuk pada saat ditanam dalam kompot.

Kegiatan penanaman bibit dilakukan setelah bibit selesai dikeringkan. Penanaman bibit muda menggunakan kompot. Cara penanaman bibit yang dilakukan yaitu membungkus bagian akar tanaman dengan media tanam spaghnum moss sebanyak segenggam kecil tangan kemudian memasukkan bagian akar tanaman yang sudah dibungkus ke dalam pot dan moss dipadatkan disekitar bibit agar bibit tertanam cukup kuat dengan menggunakan kedua ibu jari yang ditekan. Pada saat penanaman posisi bibit harus terletak di tengah pot dengan kondisi batang tenggelam atau tidak terlihat dan penekanan media tidak boleh terlalu padat juga tidak boleh kempos atau renggang. Hal ini bertujuan agar pertumbuhan akar lebih luas merata dan memiliki tanaman yang kokoh.

Masa pembibitan merupakan masa yang memiliki peranan penting dalam membentuk tanaman muda menjadi tanaman dewasa yang tumbuh secara optimal. Pada tanaman anggrek Phalaenopsis pembibitan awal dilakukan dengan menanam bibit dari botol ke dalam kompot (komunitas pot) yang disebut aklimatisasi (Aditya, 2009). Bibit kompot adalah dalam satu pot ditanam beberapa bibit secara bersama. Keuntungan menggunakan bibit kompot ini adalah mengurangi risiko kematian dan bibit mudah diamati perkembangannya semenjak awal (Iswanto, 2001). Faktor-faktor yang berpengaruh pada tahap aklimatisasi anggrek yaitu: keadaan bibit dalam botol, metode aklimatisasi, dan kondisi lingkungan saat aklimatisasi.

Pengamatan khusus yang dilakukan penulis yaitu persentase keberhasilan aklimatisasi di dua green house. Parameter yang diamati, yaitu tinggi planlet, jumlah daun, panjang daun, lebar daun, dan persentase keberhasilan aklimatisasi. Pengamatan dilakukan pada planlet usia 1 minggu setelah keluar dari botol dan pengamatan dilakukan selama tujuh minggu. Hasil pengamatan dapat dilihat pada Tabel 3.

Tabel 3. Hasil perbandingan daya tumbuh dan persentase keberhasilan aklimatisasi di dua green house

\begin{tabular}{|c|c|c|c|c|c|c|c|}
\hline \multirow{2}{*}{ Parameter } & \multicolumn{7}{|c|}{ Pengamatan minggu ke- } \\
\hline & $1 \mathrm{MSA}$ & $2 \mathrm{MSA}$ & 3 MSA & 4 MSA & $5 \mathrm{MSA}$ & $6 \mathrm{MSA}$ & $7 \mathrm{MSA}$ \\
\hline \multicolumn{8}{|l|}{ Green House 1} \\
\hline Tinggi tanaman & $1,4 \pm 0,3$ & $1,5 \pm 0,4$ & $1,5 \pm 0,4$ & $1,7 \pm 0,4$ & $2,0 \pm 0,4$ & $2,1 \pm 0,4$ & $2,1 \pm 0,4$ \\
\hline Jumlah daun & $3,6 \pm 1,0$ & $3,6 \pm 1,0$ & $3,6 \pm 1,0$ & $3,6 \pm 1,0$ & $3,6 \pm 1,3$ & $3,6 \pm 1,3$ & $3,6 \pm 0,9$ \\
\hline Panjang daun & $2,8 \pm 0,7$ & $2,9 \pm 0,7$ & $2,9 \pm 0,7$ & $2,9 \pm 0,7$ & $3,2 \pm 0,6$ & $3,3 \pm 0,7$ & $3,4 \pm 0,7$ \\
\hline Lebar daun & $1,3 \pm 0,4$ & $1,3 \pm 0,4$ & $1,3 \pm 0,4$ & $3,2 \pm 0,4$ & $1,5 \pm 0,3$ & $1,5 \pm 0,3$ & $1,6 \pm 0,4$ \\
\hline $\begin{array}{l}\text { Persentase } \\
\text { keberhasilan (\%) }\end{array}$ & \multicolumn{7}{|c|}{100} \\
\hline Green House 2 & & & & & & & \\
\hline Tinggi tanaman & $2,0 \pm 0,6$ & $2,0 \pm 0,6$ & $2,0 \pm 0,6$ & $2,0 \pm 0,6$ & $2,0 \pm 0,6$ & $2,0 \pm 0,6$ & $2,5 \pm 0,6$ \\
\hline Jumlah daun & $3,9 \pm 1,2$ & $3,9 \pm 1,2$ & $3,9 \pm 1,2$ & $3,8 \pm 1,2$ & $3,8 \pm 1,2$ & $3,8 \pm 1,1$ & $3,8 \pm 1,2$ \\
\hline Panjang daun & $3,5 \pm 1,3$ & $3,7 \pm 1,3$ & $3,8 \pm 1,3$ & $3,8 \pm 1,2$ & $4,0 \pm 1,2$ & $4,1 \pm 1,2$ & $4,2 \pm 1,2$ \\
\hline Lebar daun & $1,4 \pm 0,5$ & $1,5 \pm 0,5$ & $1,6 \pm 0,5$ & $1,7 \pm 0,6$ & $1,8 \pm 0,5$ & $1,9 \pm 0,6$ & $2,0 \pm 0,6$ \\
\hline $\begin{array}{l}\text { Persentase } \\
\text { keberhasilan }(\%)\end{array}$ & \multicolumn{7}{|c|}{100} \\
\hline
\end{tabular}

Berdasarkan pengamatan yang dilakukan di dua GH dengan mengambil sampel 50 tanaman untuk satu GH, tingkat keberhasilan aklimatisasi adalah $100 \%$ pada setiap GH. Hal tersebut karena media moss memiliki kelembaban yang baik sehingga kesegaran planlet tetap terjaga. Hal ini menunjukkan bahwa planlet dapat berdaptasi dengan lingkungan non aseptik dengan baik di dalam kompot.Secara visual bibit yang baik memperlihatkan pertumbuhan yang kuat dan segar, tidak tercemar jamur atau bakteri. Metode aklimatisasi yang menentukan keberhasilan tahap 
aklimatisasi adalah media tanam, peralatan dan cara pengeluaran serta penanaman bibit (Elmi 2001). Satsijati (1991) menyatakan bahwa media merupakan salah satu faktor lingkungan yang berfungsi menyediakan unsur hara dan air bagi pertumbuhan tanaman. Campuran dua macam media dapat memperbaiki kekurangan masingmasing media tersebut, antara lain dalam kemampuan mempertahankan kelembaban media. Menurut Sutiyoso (1997), media yang dapat digunakan untuk aklimatisasi jenis anggrek yaitu pakis cacah, moss lumut, akar kadaka, sabut kelapa, arang, dan pecahan genting.

Cara lain untuk meningkatkan keberhasilan aklimatisasi adalah dengan proses penguatan (hardening off) planlet in vitro. Hardening dapat dilakukan dengan cara menempatkan bibit botolan di luar ruang kultur, yaitu di tempat dengan suhu kamar dan cahaya matahari tidak langsung yang intensitasnya lebih tinggi selama dua minggu sebelum bibit diaklimatisasi. Hal tersebut akan membuat bibit memiliki vigor lebih baik, daun lebih hijau, dan lebih kokoh (Yusnita 2010).

Menurut (Aditya, 2009), kriteria mutu bibit aklimatisasi Phalaenopsis adalah untuk ukuran besar (daun $\geq 2$, tinggi $\geq 5 \mathrm{~cm}$, tumbuh normal), sedang (daun $\geq 2$, tinggi $\geq 4 \mathrm{~cm}$, tumbuh normal), kecil (daun $\geq 2$, tinggi $\geq 3 \mathrm{~cm}$, tumbuh normal), afkir (daun $<2$, tinggi $<3 \mathrm{~cm}$, abnormal).

\section{Pindah Tanam (Repotting)}

Pindah tanam (repotting) merupakan kegiatan pemindahan tanaman ke dalam pot yang ukurannya lebih besar. Repotting tanaman bertujuan untuk memperlancar pertumbuhan anggrek Phalaenopsis. Tanaman yang akan dilakukan repotting telah memiliki rentang waktu masing-masing ukuran sekitar empat bulan dari keluar botol. Tanaman yang akan dipindah tanam umumnya pertumbuhan akarnya terlihat banyak keluar dari kompot dan kelihatan terlalu sesak. Terdapat tiga kegiatan repotting tanaman di Hasanudin Orchids, kegiatan tersebut meliputi repotting tanaman dari tray kompot - pot 1,5", repotting tanaman dari pot 1,5" - pot 2,5", dan repotting tanaman dari pot 2,5 " - pot 3,5 ".

Pengamatan khusus yang dilakukan penulis yaitu membandingkan kemampuan tumbuh bibit di dua green house dengan 50 tanaman contoh pada setiap fasenya. Pengamatan ini dilakukan pada fase bibit (pot 1,5"), tanaman remaja (pot 2,5"), dan dewasa (pot 3,5"). Parameter yang diamati yaitu tinggi tanaman, jumlah daun, panjang daun, dan lebar daun yang diamati selama tujuh minggu. Berdasarkan hasil pengamatan, didapatkan hasil rata-rata jumlah daun, panjang daun, dan lebar daun sebagai berikut.

Tabel 4. Rata-rata tinggi tanaman bibit, tanaman remaja, dan tanaman dewasa

\begin{tabular}{|c|c|c|c|c|c|c|c|}
\hline \multirow{3}{*}{ Parameter } & \multicolumn{7}{|c|}{ Pengamatan minggu ke- } \\
\hline & & & ----- & -----cm---- & ------- & & \\
\hline & $1 \mathrm{MSP}$ & $2 \mathrm{MSP}$ & 3 MSP & 4 MSP & 5 MSP & $6 \mathrm{MSP}$ & 7 MSP \\
\hline \multicolumn{8}{|l|}{ Green House 1} \\
\hline Bibit (1,5”) & $2,8 \pm 0,7$ & $2,8 \pm 0,7$ & $2,9 \pm 0,7$ & $3,0 \pm 0,7$ & $3,0 \pm 0,7$ & $3,0 \pm 0,7$ & $3,0 \pm 0,7$ \\
\hline $\begin{array}{l}\text { Tanaman remaja } \\
(2,5 ”)\end{array}$ & $8,5 \pm 1,7$ & $8,8 \pm 1,8$ & $8,8 \pm 1,8$ & $9,3 \pm 1,9$ & $9,3 \pm 1,9$ & $9,4 \pm 2,0$ & $9,4 \pm 2,0$ \\
\hline $\begin{array}{l}\text { Tanaman dewasa } \\
(3,5 \text { ”) }\end{array}$ & $18 \pm 3,7$ & $18 \pm 3,8$ & $18 \pm 3,8$ & $18 \pm 3,8$ & $18 \pm 3,8$ & $18 \pm 3,8$ & $18 \pm 3,8$ \\
\hline \multicolumn{8}{|l|}{ Green House 2} \\
\hline Bibit $(1,5 ”)$ & $2,7 \pm 0,6$ & $2,7 \pm 0,6$ & $3,0 \pm 0,7$ & $3,0 \pm 0,7$ & $3,0 \pm 0,7$ & $3,0 \pm 0,7$ & $3,6 \pm 0,7$ \\
\hline $\begin{array}{l}\text { Tanaman remaja } \\
(2,5 ")\end{array}$ & $8,8 \pm 1,8$ & $8,8 \pm 1,8$ & $9,1 \pm 1,9$ & $9,5 \pm 2,1$ & $9,5 \pm 2,1$ & $9,5 \pm 2,1$ & $9,6 \pm 2,2$ \\
\hline $\begin{array}{l}\text { Tanaman dewasa } \\
(3,5 \text { ") }\end{array}$ & $21 \pm 4,2$ & $21 \pm 4,2$ & $21 \pm 4,2$ & $21 \pm 4,2$ & $21 \pm 4,2$ & $21 \pm 4,2$ & $21 \pm 4,2$ \\
\hline
\end{tabular}

Pengamatan tinggi tanaman dilakukan dengan cara mengukur tinggi batang tanaman dari permukaan media moss hingga ujung daun terpanjang. Berdasarkan hasil pengamatan ratarata tinggi tanaman, dapat dilihat bahwa tinggi tanaman pada bibit, tanaman remaja, dan dewasa di GH 2 lebih tinggi dibandingkan pada GH 1. Hal ini dapat disebabkan oleh faktor cahaya, karena GH 2 mendapatkan cahaya matahari yang cukup sehingga pertumbuhan tinggi tanaman anggrek optimum.

Penggunaan naungan dalam budidaya anggrek sangat penting. Cahaya matahari sangat penting untuk berlangsungnya proses fotosintesis yang akan menghasilkan energi untuk tanaman agar dapat tumbuh dan berkembang dengan baik. Sehingga, bila kekurangan cahaya maka pertumbuhan akan terhambat, namun di sisi lain jika kelebihan cahaya maka akan mengakibatkan 
kerusakan pada tanaman, seperti klorosis dengan gejala ujung tanaman mengering. Pemilihan naungan yang tepat agar memberikan cahaya pada tingkat optimum sangat diperlukan untuk menghasilkan anggrek yang berkualitas.

Tabel 5. Rata-rata jumlah daun bibit, tanaman remaja, dan tanaman dewasa

\begin{tabular}{|c|c|c|c|c|c|c|c|}
\hline \multirow{2}{*}{ Parameter } & \multicolumn{7}{|c|}{ Pengamatan minggu ke- } \\
\hline & $1 \mathrm{MSP}$ & 2 MSP & 3 MSP & 4 MSP & $5 \mathrm{MSP}$ & 6 MSP & 7 MSP \\
\hline \multicolumn{8}{|l|}{ Green House 1} \\
\hline Bibit (1,5”) & $3,9 \pm 1,0$ & $3,9 \pm 0,9$ & $4,2 \pm 0,9$ & $4,2 \pm 1,0$ & $4,4 \pm 1,0$ & $4,4 \pm 1,0$ & $4,4 \pm 1,0$ \\
\hline $\begin{array}{l}\text { Tanaman remaja } \\
(2,5 ”)\end{array}$ & $4,2 \pm 1,3$ & $4,3 \pm 1,5$ & $4,4 \pm 1,5$ & $4,5 \pm 1,4$ & $4,6 \pm 1,5$ & $4,6 \pm 1,5$ & $4,6 \pm 1,5$ \\
\hline $\begin{array}{l}\text { Tanaman dewasa } \\
\left(3,5^{\prime \prime}\right)\end{array}$ & $3,4 \pm 1,1$ & $3,6 \pm 1,2$ & $3,6 \pm 1,2$ & $3,7 \pm 1,3$ & $3,8 \pm 1,3$ & $3,8 \pm 1,2$ & $3,8 \pm 1,2$ \\
\hline \multicolumn{8}{|l|}{ Green House 2} \\
\hline Bibit (1,5”) & $4,1 \pm 1,5$ & $4,3 \pm 1,4$ & $4,2 \pm 1,4$ & $4,2 \pm 1,4$ & $4,3 \pm 1,4$ & $4,3 \pm 1,4$ & $4,3 \pm 1,2$ \\
\hline $\begin{array}{l}\text { Tanaman remaja } \\
(2,5 ”)\end{array}$ & $3,3 \pm 1,0$ & $3,3 \pm 0,9$ & $3,3 \pm 0,9$ & $3,3 \pm 0,9$ & $3,5 \pm 1,0$ & $3,6 \pm 1,0$ & $3,6 \pm 1,0$ \\
\hline $\begin{array}{l}\text { Tanaman dewasa } \\
(3,5 ")\end{array}$ & $3,6 \pm 1,0$ & $3,6 \pm 0,9$ & $3,6 \pm 0,9$ & $3,7 \pm 1,0$ & $3,7 \pm 0,3$ & $3,8 \pm 0,8$ & $3,8 \pm 0,5$ \\
\hline
\end{tabular}

Perhitungan jumlah daun dihitung dari daun terbawah yang masih hijau dan sehat hingga daun teratas tanaman. Kemunculan daun baru, dihitung sebagai satu daun jika telah tumbuh dan berkembang menjadi daun muda. Menurut Sitompul dan Guritno (1995), jumlah daun merupakan salah satu indikator pertumbuhan tanaman dan dapat digunakan sebagai data penunjang untuk menjelaskan proses pertumbuhan yang terjadi. Glover (2007), menyatakan bahwa peningkatan jumlah daun akan membuat tanaman mampu melakukan fotosintesis secara maksimal untuk mendukung proses transisinya menuju fase reproduktif. Menurut Dirjen P2HP (2005), kriteria jumlah daun tanaman anggrek Phalanenopsis dalam pot 1,5" adalah 3 daun, pot 2,5" 3,5 daun, dan pada pot 3,5 " adalah 4 daun.
Berdasarkan pengamatan rata-rata jumlah daun (Tabel 7) dapat dilihat bahwa rata-rata jumlah daun pada bibit 1,5 " di green house 1 lebih banyak dibandingkan dengan green house 2 . Namun jika dilihat dari rata-rata jumlah daun setiap minggunya, dari minggu pertama hingga minggu keempat jumlah daun di green house 2 mengalami penurunan, sedangkan pada green house 1 terus meningkat. Pada tanaman remaja 2,5" jumlah daun di green house 2 lebih rendah dibandingkan pada green house 1. Pada tanaman dewasa 3,5" rata-rata jumlah daun di green house 2 lebih rendah dibandingkan pada green house 1. Berdasarkan analisa visual rata-rata jumlah daun pada green house 2 lebih rendah dibandingkan dengan green house 1. Hal ini dikarenakan banyaknya daun yang mati terkena hama dan penyakit tanaman pada green house 2 yang menyebabkan rata-rata jumlah daun menurun.

Tabel 6. Rata-rata panjang daun bibit, tanaman remaja, dan tanaman dewasa

\begin{tabular}{|c|c|c|c|c|c|c|c|}
\hline \multirow{3}{*}{ Parameter } & \multicolumn{7}{|c|}{ Pengamatan minggu ke- } \\
\hline & & & & -----cm----- & ------- & & \\
\hline & 1 MSP & $2 \mathrm{MSP}$ & 3 MSP & 4 MSP & $5 \mathrm{MSP}$ & $6 \mathrm{MSP}$ & 7 MSP \\
\hline \multicolumn{8}{|l|}{ Green House 1} \\
\hline Bibit $(1,5 ”)$ & $5,0 \pm 1,4$ & $5,3 \pm 1,4$ & $5,3 \pm 1,5$ & $5,3 \pm 1,5$ & $5,5 \pm 1,6$ & $5,6 \pm 1,6$ & $5,8 \pm 1,6$ \\
\hline $\begin{array}{l}\text { Tanaman remaja } \\
\left(2,5^{\prime \prime}\right)\end{array}$ & $7,0 \pm 1,6$ & $8,1 \pm 1,6$ & $8,2 \pm 1,6$ & $8,3 \pm 1,6$ & $8,5 \pm 1,6$ & $8,7 \pm 1,6$ & $8,8 \pm 1,6$ \\
\hline $\begin{array}{l}\text { Tanaman dewasa } \\
\left(3,5^{\prime \prime}\right)\end{array}$ & $10 \pm 2,3$ & $10 \pm 2,3$ & $10 \pm 2,3$ & $10 \pm 2,4$ & $10 \pm 2,4$ & $10 \pm 2,3$ & $11 \pm 2,3$ \\
\hline \multicolumn{8}{|l|}{ Green House 2} \\
\hline Bibit (1,5”) & $6,1 \pm 1,0$ & $6,1 \pm 1,2$ & $6,2 \pm 1,2$ & $6,3 \pm 1,3$ & $6,4 \pm 1,2$ & $6,5 \pm 1,2$ & $6,6 \pm 1,1$ \\
\hline $\begin{array}{l}\text { Tanaman remaja } \\
(2,5 ”)\end{array}$ & $7,5 \pm 1,5$ & $7,7 \pm 1,6$ & $7,8 \pm 1,6$ & $7,8 \pm 1,6$ & $8,1 \pm 1,6$ & $8,3 \pm 1,7$ & $8,6 \pm 1,8$ \\
\hline $\begin{array}{l}\text { Tanaman dewasa } \\
(3,5 \text { ") }\end{array}$ & $13 \pm 2,6$ & $13 \pm 2,5$ & $13 \pm 2,5$ & $13 \pm 2,8$ & $14 \pm 2,7$ & $14 \pm 2,8$ & $14 \pm 2,8$ \\
\hline
\end{tabular}

Berdasarkan pengamatan rata-rata panjang daun (Tabel 6) dapat dilihat bahwa bibit, tanaman remaja, dan tanaman dewasa di green house 2 memiliki daun yang lebih panjang dibandingkan dengan bibit yang berada di green house 1. Pada green house 1 rata-rata panjang daun bibit pada 7 MSP 5,8 cm, sedangkan pada green house 2 adalah $6,6 \mathrm{~cm}$. Tanaman remaja di 
green house 1 memiliki nilai rata-rata panjang daun $8,8 \mathrm{~cm}$ namun, pada green house 2 adalah $8,6 \mathrm{~cm}$. Tanaman dewasa pada green house 1 memiliki rata-rata panjang daun $11 \mathrm{~cm}$ dan pada green house 2 adalah $14 \mathrm{~cm}$. Hal ini dapat dikarenakan bahwa ketinggian tempat yang hanya berbeda 90 meter diatas permukaan laut tidak menunjukkan perbedaan yang tinggi pada panjang daun.

Tabel 7. Rata-rata lebar daun bibit, tanaman remaja, dan dewasa

\begin{tabular}{|c|c|c|c|c|c|c|c|}
\hline \multirow[b]{2}{*}{ Parameter } & \multicolumn{7}{|c|}{ Pengamatan minggu ke- } \\
\hline & $1 \mathrm{MSP}$ & $2 \mathrm{MSP}$ & $3 \mathrm{MSP}$ & $4 \mathrm{MSP}$ & $5 \mathrm{MSP}$ & $6 \mathrm{MSP}$ & $7 \mathrm{MSP}$ \\
\hline \multicolumn{8}{|l|}{ Green House 1} \\
\hline Bibit $(1,5 ")$ & $2,0 \pm 0,4$ & $2,1 \pm 0,5$ & $2,1 \pm 0,5$ & $2,1 \pm 0,5$ & $2,3 \pm 0,5$ & $2,5 \pm 0,5$ & $2,6 \pm 0,4$ \\
\hline $\begin{array}{l}\text { Tanaman remaja } \\
\left(2,5^{\prime \prime}\right)\end{array}$ & $2,4 \pm 0,5$ & $2,5 \pm 0,5$ & $2,5 \pm 0,5$ & $2,5 \pm 0,5$ & $2,7 \pm 0,5$ & $3,0 \pm 0,6$ & $3,1 \pm 0,6$ \\
\hline $\begin{array}{l}\text { Tanaman dewasa } \\
\left(3,5^{\prime \prime}\right)\end{array}$ & $3,8 \pm 0,6$ & $3,9 \pm 0,6$ & $3,9 \pm 0,6$ & $4,1 \pm 0,6$ & $0,6 \pm 0,6$ & $0,6 \pm 0,6$ & $4,3 \pm 0,6$ \\
\hline \multicolumn{8}{|l|}{ Green House 2} \\
\hline Bibit (1,5”) & $2,0 \pm 0,4$ & $2,1 \pm 0,5$ & $2,1 \pm 0,5$ & $2,2 \pm 0,5$ & $2,3 \pm 0,6$ & $2,4 \pm 0,6$ & $2,5 \pm 0,5$ \\
\hline $\begin{array}{l}\text { Tanaman remaja } \\
(2,5 \text { ") }\end{array}$ & $3,2 \pm 0,5$ & $3,3 \pm 0,5$ & $3,3 \pm 0,5$ & $3,4 \pm 0,6$ & $3,5 \pm 0,7$ & $3,6 \pm 0,7$ & $3,8 \pm 0,7$ \\
\hline $\begin{array}{l}\text { Tanaman dewasa } \\
\left(3,5^{\prime \prime}\right)\end{array}$ & $4,3 \pm 0,6$ & $4,3 \pm 0,5$ & $4,4 \pm 0,6$ & $4,4 \pm 0,6$ & $4,5 \pm 0,6$ & $4,7 \pm 0,6$ & $4,8 \pm 0,7$ \\
\hline
\end{tabular}

Berdasarkan hasil pengamatan (Tabel 7) dapat dilihat bahwa bibit, tanaman remaja, dan dewasa di green house 2 memiliki daun lebih lebar dibandingkan dengan bibit di green house 1. Lebar daun rata-rata pada bibit di green house 2 adalah $2,5 \mathrm{~cm}$, tanaman remaja $3,8 \mathrm{~cm}$, dan tanaman dewasa $4,8 \mathrm{~cm}$. Berawal dari pengamatan minggu pertama hingga minggu terakhir lebar daun bibit, tanaman remaja dan dewasa terus mengalami peningkatan. Hal ini dikarenakan letak green house 2 mendapatkan cahaya matahari optimum. Cahaya matahari dapat mempengaruhi lebar daun. Cahaya matahari yang cukup membuat lebar daun semakin luas, sebaliknya jika kekurangan cahaya matahari daun akan memanjang, kurus, lemas dan berwarna hijau tua.

\section{Pemeliharaan Tanaman}

Pemeliharaan tanaman terutama pada masa pembibitan. Hal ini untuk menjaga kualitas tanaman yang dihasilkan agar mampu meningkatkan produktivitas. Pemupukan merupakan pemberian unsur hara yang dibutuhkan tanaman untuk tumbuh dan berkembang dengan baik. Pupuk dibagi menjadi dua, yaitu pupuk anorganik dan pupuk organik. Penyiraman pemupukan rutin dilakukan dua kali dalam seminggu. Pupuk utama yang digunakan yaitu pupuk anorganik dengan kandungan NPK 20: 20: 20. Menurut Kencana (2007), masa pembibitan yang merupakan fase vegetatif tanaman membutuhkan pupuk dengan kandungan N lebih tinggi, misalnya pupuk NPK 30: 10:10. Pihak perusahaan memakai pupuk dengan kandungan NPK seimbang agar tanaman mendapatkan suplai hara yang seimbang, sehingga pertumbuhannya pun ikut seimbang baik vegetatif dan generatifnya. Pupuk Mamigro yang digunakan perusahaan memiliki komposisi utama, yaitu unsur hara makro (N, P, K, Ca, Mg, dan S) dan unsur hara mikro $(\mathrm{Cu}, \mathrm{Co}, \mathrm{B}, \mathrm{Mo}, \mathrm{Mn}, \mathrm{Zn}$, dan unsur lain yang diperlukan tanaman). Dosis pemakaian pupuk tersebut $1 \mathrm{~g} \mathrm{~L}^{-1}$ minggu.

Dalam berusaha tani anggrek, serangan OPT merupakan salah satu faktor pembatas untuk meningkatkan produksi. Jika tidak dilakukan pengendalian, dapat mengakibatkan menurunya kualitas atau nilai estetika dari tanaman hias tersebut, sehingga harga jual tanaman juga dapat menurun. Akibat selanjutnya terhadap kehadiran OPT yaitu dapat menyebabkan kematian pada tanaman anggrek. Jenis-jenis OPT yang paling dominan menyerang kebun anggrek, melalui identifikasi berdasarkan morfologi, antara lain: tungau merah Tenuipalpus pacificus Baker (Zhang 2003), bekicot Achatina fulica (Karyatiningsih et al. 2008), dan Pestalotia sp., yang diidentifikasikan sebagai Pestalotia palmarum Cke. (Semangun, 2007).

Perusahaan menggunakan pestisida sintetis karena dianggap sebagai tindakan yang paling ampuh untuk mencegah serta mengatasi serangan OPT tersebut. Namun, untuk jenis hama tertentu seperti bekicot, perusahaan biasanya melakukan pengendalian secara mekanis, yaitu dengan mengambil dan mengumpulkan hama tersebut secara langsung jika ditemukan, kemudian mematikannya. Berdasarkan data dari hasil wawancara dan pengamatan di kebun, terdapat beberapa hama dan penyakit pada tanaman anggrek Phalaenopsis. Masalah hama dan penyakit menjadi masalah utama karena 
serangannya dapatmenrunkan hasil yang tingi. Hama dan penyakit tersebut antara lain dapat

Tabel 8. Hama dan penyakit pada anggrek Phalaenopsis

\begin{tabular}{ccccccc}
\hline \multirow{2}{*}{ Hama dan Penyakit } & \multicolumn{2}{c}{ Jumlah Tanaman } & \multicolumn{2}{c}{ Jumlah Tanaman yang Terserang } & \multicolumn{2}{c}{$\begin{array}{c}\text { Persentase Tanaman yang } \\
\text { Terserang (\%) }\end{array}$} \\
\cline { 2 - 7 } & \multirow{2}{*}{ GH 1 } & \multirow{2}{*}{ GH 2 } & GH 1 & GH 2 & GH 1 & GH 2 \\
\hline Siput & & & 3 & 7 & 1,50 & 3,50 \\
Semut & \multirow{2}{*}{200} & \multirow{2}{*}{200} & 60 & 50 & 30,00 & 25,00 \\
Kutu putih & & & 5 & 12 & 4,50 & 6,00 \\
Busuk lunak & & & 5 & 10 & 2,50 & 5,00 \\
\hline
\end{tabular}

Berdasarkan hasil pengamatan (Tabel 8) hama dan penyakit yang terdapat di green house 1 dan 2 adalah hama siput, semut, kutu putih, dan penyakit busuk lunak. Tanaman pada green house 2 lebih banyak terserang hama dan penyakit, hama siput $3,5 \%$, semut $25 \%$, kutu putih $6 \%$, dan penyakit busuk lunak $5 \%$. Indikasi penyebab tanaman terkena hama dan penyakit dapat disebabkan oleh perawatan dan pengendalian dari para petani, karena setiap green house dikelola oleh petani yang berbeda. Hama dan penyakit tanaman jika dibiarkan terus menerus akan menurunkan produksi dan kualitas yang dihasilkan oleh perushaan. Pengendalian hama dan penyakit dilakukan secara kimia menggunakan fungisida dan bakterisida. Kegiatan ini dilakukan sebanyak dua minggu sekali. Sama halnya dengan pemupukan, aplikasi penggunaan bahan-bahan pestisida telah disesuaikan oleh perusahaan.

Siput merupakan hama yang paling sering merusak tanaman anggrek. Kerusakan yang ditimbulkan akibat serangan siput cukup besar. Akar-akar muda, tunas baru, dan kuncup bunga adalah makanan bagi siput. Anggrek Phalaenopsis merupakan tanaman anggrek yang paling sering diserang oleh siput. Pengendaliannya dapat dilakukan secara mekanis dengan mengambil dan mengumpulkannya.

Serangan hama semut dapat menyebabkan tanaman rusak pada bagian akar dan tunas mudanya. Hal ini disebabkan oleh jamur yang dibawa oleh semut tersebut. Cara pengendaliannya adalah dengan merendam pot dalam air. Cara ini baik untuk mencegah hama semut datang krmbali. Selain merendam kebersihan pot harus diperhatikan dengan baik.

Kutu putih berukuran kecil dan berwarna kelabu kemerahan. Terdapat pada titik tumbuh, diketiak daun dan pada akar gantung. Kutu ini melindungi dirinya dengan bahan halus seperti kapas berwarna putih. Hidupnya bersimbiosis dengan semut. Pengendaliannya dapat dilakukan penyemprotan dengan fungisida dan bakterisida.
Gejala penyakit busuk daun ini ditandai dengan timbulnya bercak yang berwarna lebih gelap dibandingkan dengan daun yang sehat. Selanjutnya daun menjadi lunak dan berair, turgornya hilang, dan mengeluarkan bau yang khas. Penyakit ini akan menjalar ke bagian pucuk tanaman (titik tumbuh) sehingga dalam waktu singkat tanaman akan mati. Pemberantasan yang dilakukan pada umumnya adalah memotong daun yang terserang penyakit atau membuang tanaman tersebut.

\section{KESIMPULAN}

Kegiatan penelitian yang dilakukan di Hasanudin Orchids, Batu, Jawa Timur memberikan pengetahuan dan pengalaman dalam melakukan kegiatan teknis budidaya anggrek Phalaenopsis. Pembuatan media kultur di Hasanudin Orchids ada dua, yaitu media PDA dan media VW. Kontaminasi pada pembesaran planlet banyak terjadi pada sub kultur 1 dan 2 yaitu sebesar 28 dan $20 \%$. Tingkat keberhasilan pada aklimatisasi adalah $100 \%$. Perbandingan daya tumbuh bibit, tanaman remaja, dan dewasa pada dua green house tidak menunjukkan perbedaan yang tinggi, namun sedikit lebih baik pertumbuhannya pada green house 2 . Pemeliharaan tanaman, terutama pada pengendalian hama dan penyakit tanaman masih rendah. Pemeliharaan dan perawatan dilakukan oleh petani yang berbeda.

\section{DAFTAR PUSTAKA}

Aditya, E.N.R. 2009. Budidaya Tanaman Anggrek : Pengelolaan Pembibitan Anggrek Phalaenopsisdi PT. Ekakarya Graha Flora, Cikampek, Jawa Barat. [Skripsi]. Fakultas Pertanian. Bogor (ID): Institut Pertanian Bogor.

Amilah, A. Yuni. 2006. Pengaruh Konsentrasi Ekstrak Taoge dan Kacang Hijau pada 
Media Vacin and Went (VW) terhadap Pertumbuhan Kecambah Anggrek Bulan (Phalaenopsis amabilis L.). Bulletin Penelitian.No. 09.

Badan Pusat Statistika. 2015. Data Produksi Tanaman Hias Indonesia Tahun 2013-2015. Badan Pusat Statistika. Jakarta Barat.

Bey, Y., W. Syafii, N. Ngatifah. 2005. Pengaruh Pemberian Giberelin Pada Media Vacint dan Went terhadap Perkecambahan Biji Anggrek Bulan (Phalaenopsis amabilis B.L) Secara In Vitro. J. Biogenesis.Vol 1(2):57-61.

Corduk, O. Nursen, Cuneyt Aki. 2011. Inhibition of Browning Problem During Micropropagation of Sideritis trojana bornm. An Endemic Medicinal Herb of Turkey. Romanian Biotechnological Letters. Vol. 16 No. 6.

[Dirjen P2HP] Direktorat Jenderal Pengolahan dan Pemasaran Hasil Pertanian. 2010. Pasca Panen dan Pemasaran Anggrek, 2005-2010. Jakarta (ID): Dirjen P2HP.

Dutta, S., A. Chowdurry, B. Bhattacharjee, P. K. Nath, B. K. Dutta. 2011. In vitro Multiplication and Protocorm Development of Dendrobium aphyllum (Roxb.) CEC Fisher. Biological and Environmental Science. 7 (1): 57-62.

Elmi, S. 2001. Masa Kritis dalam Penanaman Bibit Anggrek dalam Botol. Surabaya (ID): East Java Orchid.

Handini, A.S. 2012. Pengaruh Paclobutrazol terhadap Pertumbuhan Anggrek Dendrobium lasianthera pada Tahap Aklimatisasi [Skripsi]. Fakultas Pertanian. Bogor (ID): Institut Pertanian Bogor.

Iswanto, H. 2001. Anggrek Phalaenopsis. Jakarta. Agromedia Pustaka. 48 hal.

Kencana, I. P. 2007. Cara Cepat Membungakan Anggrek. Gramedia. Jakarta. 64 hal.

Laukkanen, H., H. Haggman, S.K. Soppela, and A. Hohtola. 1999. Tissue Browning of In
VitroCultures of Scots Pine: Role of Peroxidase and Polyphenol Oxidase. Physiol. Plant. 106(3):337-343.

Morel, G.M. 1974. Clonal Multiplication of Orchid. The Orchid Scientific Studies. Wiley-Interscience Publication. John Wileyand Sons, New York.

Satsijati. 1991. Pengaruh media tumbuh terhadap pertumbuhan bibit anggrek Dendrobium. J. Hort. 3:15-22.

Semangun, H. 2007. Penyakit-Penyakit Tanaman Hortikultura di Indonesia edisi ketiga. Yogyakarta: UGM Press.

Sutiyoso, Y. 1997. Syarat dan jenis media tanam anggrek. Bul. PAI. 5(9):11-17.

Widiastoety, D., F.A. Bahar. 1995. Pengaruh Intensitas Cahaya Terhadap Pertumbuhan Anggrek Dendrobium. J. Hort. 4 (5) : 7275.

Young, P.S., H.N. Murty, P.K. Yeuep. 2001. Mass multiplication of protocorm-like bodies using bioreactor system and subsequent plant regeneration in Phalaenopsis. Plant Cell, Tissue and Organ Cult. 63:67-72.

Yusnida, B., W. Syafii, Sutrisna. 2006. Pengaruh giberelin (GA3) dan air kelapa terhadap perkecambahan biji anggrek bulan (Phalaenopsis amabilis BL) secara in vitro. J. Biogenesis 2:41-26.

Yusnita. 2010. Perbanyakan In Vitro Tanaman Anggrek. Lampung (ID): Universitas Lampung.

Yusnita. 2012. Pemuliaan Tanaman Untuk Menghasilkan Anggrek Hibrida Unggul. Lembaga Penelitian Universitas Lampung. Lampung.

Zhang, Z.Q. 2003. Mites of Greenhouse Identification, Biology, and Control. Aucland: $\quad$ CABI Publishing. 